DOI: 10.33766/2524-0323.89.221-228

УДК 342.951: 364.3: 61 (477)

Я. М. Шатковський, кандидат юридичних наук, старший науковий співробітник, докторант Запорізького національного університету

(м. Запоріжжя, Україна) e-mail: akt11@ukr.net iDhttps://orcid.org/0000-0001-9205-9445

\title{
ЗАПРОВАДЖЕННЯ ОБОВ'ЯЗКОВОГО МЕДИЧНОГО СТРАХУВАННЯ ЯК ПУБЛІЧНО-ПРАВОВИЙ КРОК ДО ПІДВИЩЕННЯ ДОСТУПНОСТІ МЕДИЧНОЇ ДОПОМОГИ В УКРАЇНІ
}

У статті розглядаються питання запровадження обов'язкового медичного страхування у якості шляху підвищення доступності медичної допомоги. Акцентується увага на існуючих проблемах вітчизняної охорони здоров'я крізь призму ії правового забезпечення. Критично сприймається рішення Конституційного Суду України, який зазначив про те, що право особи на медичне страхування, передбачене в статті 49 Конституції України, - це право на добровільне, а не обов'язкове медичне страхування. Зазначається про відмінності добровільного та обов'язкового медичного страхування.

Ключові слова: обов'язкове медичне страхування; доступність медичної допомоги; права пацієнтів, адміністративне право; медичне право.

Постановка проблеми. Наразі питання правового забезпечення медичної діяльності характеризуються підвищеною актуальністю. Причин тому є багато; вкажемо лише ключові із них: незадоволеність населення якістю та доступністю медичної допомоги; неможливість для частини населення за територіальною віддаленістю отримати медичну допомогу поряд із місцем проживання узагалі; законодавство про медичну діяльність не відповідає реаліям сьогодення; медична реформа носить «хронічний» характер і не призводить до покращенню стану справ у вітчизняній медицині; незапровадження обов' язкового медичного страхування; первинна ланка медичної допомоги, як найбілыш наближена до людини, потребує суттєвого оновлення.

Аналіз останніх досліджень і публікацій. Загальні положення, присвячені правовому регулюванню медичної діяльності, медичному праву, запровадженню в Україні обов' язкового медичного страхування розглядались у працях таких дослідників, як: В. О. Галай, В. Ф. Москаленко, З. О. Надюк, О. Г. Пелагеша, М. І. Пришляк, Л. О. Самілик, О. Л. Сіделковський, О. В. Солдатенко, Р. О. Стефанчук, В.Ю.Стеценко, С. Г. Стеценко, Т. О. Тихомирова, Г. М. Токарєв, Д. М. Шатковська, Н. В. Шевчук та ін. Проте наразі в правовій науці недостатньо розробленими залишаються питання, присвячені запровадженню обов' язкового медичного страхування в якості кроку, спрямованого на підвищення доступності медичної допомоги.

Формулювання цілей. Метою цієї статті є розкриття правових особливостей запровадження обов' язкового медичного страхування як публічно-правового кроку до підвищення доступності медичної допомоги в Україні.

Виклад основного матеріалу. На наше переконання, актуальність розгляду та дослідження ролі української медичної реформи в контексті реформи первинної

(C) Шатковський Я. М., 2020 
ланки медичної допомоги та підвищення доступності медичної допомоги пояснюється наступним: по-перше, за кращими світовими зразками організації надання медичної допомоги, до 70 \% іiі обсягів надається саме на первинному рівні. Враховуючи, що метою реформи медичної галузі в Україні є наближення до кращих прикладів іiі функціонування у світі, постає питання про зростання обсягів первинної медичної допомоги у структурі медичної допомоги загалом; по-друге, цей вид медичної допомоги є максимально наближеним до пересічного громадянина. Житель сільської місцевості, який проживає за білыш ніж сотню кілометрів до обласного центру, можливо, ніколи за своє життя і не користуватиметься послугами високоспеціалізованої медичної допомоги, проте він гарантовано в певні періоди свого життя звернеться за первинною медичною допомогою (сільський фельдшерськоакушерський пункт, районна поліклініка тощо); по-третє, формально кажучи, у рамках нинішнього етапу медичної реформи, модернізується саме первинна ланка. За ії результатами, автори планують запропонувати реформування інших сегментів організації медичної допомоги населенню; по-четверте, терміносполучення «кошти слідують за пацієнтом», яке раніше носило для вітчизняної медицини теоретичний зміст, наразі отримує чітке практичне наповнення: за кожного пацієнта надавач медичної допомоги отримає конкретні кошти від держави (у широкому розумінні), що реалізовуватиметься через створений центральний орган виконавчої влади Національну службу здоров'я України; i, насамкінець, по-п'яте, пацієнт отримає можливість реального вибору, адже саме він обиратиме ту лікувальну установу, того лікаря, який надаватиме йому первинну медичну допомогу, із можливістю їх заміни, якщо він вважатиме це за доцільне [1, с. 133].

Важливим чинником, який здатен покращити доступність медичної допомоги, є законодавче запровадження обов' язкового медичного страхування. Цей крок, який при збереженні безоплатності медичної допомоги в державних та комунальних закладах охорони здоров'я здатен забезпечити новий організаційно-правовий та фінансовий характер взаємовідносин між різними суб'єктами, залученими до надання медичної допомоги. Неодмінною ознакою законодавчого запровадження обов' язкового медичного страхування мають стати консультащії 3 громадськістю передусім шляхом проведення громадських обговорень, які «є важливою складовою прийняття білышості важливих для держави та суспільства рішень» [2, с. 38].

С. Г. Стеценко справедливо стверджує, що, говорячи про безоплатну медичну допомогу, ми маємо констатувати, що це надбання радянського періоду існування нашої держави. Не даючи політичних оцінок тому часові, маємо констатувати, що, за великим рахунком, багато в чому безоплатність при отриманні медичної допомоги відповідала дійсності. I в цьому сенсі до охорони здоров'я державою застосовувались схожі підходи, як і до культури, освіти, науки, соціального захисту населення. Такого роду стратегія була домінантою радянського способу організащії народного господарства: у певних напрямах регулювання суспільного життя констатувалось суттєве відставання від провідних економічно розвинутих країн світу, натомість охорона здоров'я та інші соціальні зобов'язання держави були безоплатними та на відносно належному рівні [3, с. 42-43].

Поряд із безоплатним для людини характером надання медичної допомоги, що може потенщійно бути забезпечене через запровадження обов'язкового медичного 
страхування, важливо з позищій адміністративно-правового регулювання акцентувати увагу на формуванні єдиного медичного простору. Це теж важливий крок, який спрямований на покращення доступності медичної допомоги. Ми погоджуємося із О. Л. Сіделковським, який зазначає, що станом на сьогодні ми є свідками низки негативних соціально-правових явищ, які мають місце в Україні, зокрема: підвищення показників захворюваності, зниження тривалості та якості життя, зменшення чисельності населення нашої держави, складнощі в організаційно-правовому забезпечення охорони здоров'я. Як видається, одним із важливих кроків, спрямованих на подолання цих негативних явищ, може стати створення та підтримка функціонування єдиного медичного простору [4, с. 176]. Запровадження обов'язкового медичного страхування також є вагомим кроком щодо подолання корупщії в медичній сфері, у тому числі й шляхом залучення громадськості до цього процесу [5, с. 5-6].

Повертаючись до запровадження обов'язкового медичного страхування констатуємо, що основним механізмом його втілення в життя є адміністративно-правовий. Чому саме адміністративне право? На нашу думку, є ціла низка причин, котрі зумовлюють переважно адміністративно-правове регулювання суспільних відносин у сфері обов' язкового медичного страхування. Ключовими серед них можна вважати:

- переважно публічно-правові механізми регулювання обов'язкового медичного страхування, що пов' язані зі значним впливом держави на запровадження цього соціального за своєю природою виду страхування;

- взаємовідносини органів виконавчої влади 3 новоствореними структурами обов' язкового медичного страхування (фонди обов' язкового медичного страхування, страхові медичні компанії, лікувально-профілактичні заклади);

- контроль за функціонуванням системи обов' язкового медичного страхування щодо відповідності лікувальних закладів та страхових медичних організацій встановленим законодавством вимогам;

- побудову організаційних механізмів обов'язкового медичного страхування, зокрема процес узгодження тарифів на медичні послуги, процедури вибору страхової компанії, лікувального закладу, видачу страхових полісів;

- гарантії з боку держави щодо можливості для громадянина безоплатно отримати належної якості медичну допомогу.

Справедливості заради зазначимо, що чинна Конституція України в статті 49 передбачила медичне страхування. Основний закон держави так формулює це положення: Кожен має право на охорону здоров'я, медичну допомогу та медичне страхування [6]. Проте Конституційний Суд, у 2002 році розтлумачив це положення в такий спосіб, що «на підставі дослідження Конституційний Суд України вважає, що частина перша статті 49 Конституції України закріплює право кожного на медичне страхування, тобто не обов'язкове, а добровільне медичне страхування громадян [7]. Ми не можемо вважати таке рішення ідеальним. Багато фахівців стверджують, що воно задало неправильний формат парадигмі конституційно-правового регулювання обов' язкового медичного страхування. С. Г. Стеценко наголошує на недоцільному векторі розвитку медичного страхування в Україні, який було спричинено вказаним рішення єдиного органу конституційної юрисдикції. При першому наближенні позищія КСУ стосовно того, що в статті 49 мова йде саме про добровільне медичне страхування, видається доцільною. Проте більш детальний аналіз дає підстави до певних сумнівів за рахунок наступного. Розуміння термінів 
«обов' язковий» та «добровільний» свідчать про те, що перший із них носить імперативний характер, зобов'язує суб'єкта до вчинення певних дій, підкріплений засобами державного примусу та притягнення до відповідальності у разі невиконання даних дій; другий же, навпаки, диспозитивний, надає можливість вибору оптимальної моделі поведінки, підтримує «добру волю» суб'єкта. У контексті медичного страхування мова має йти не про особу, а про державу. Автори Основного закону держави, як видається, говорячи про медичне страхування, мали на увазі саме обов' язкове страхування (під ним ми розуміємо вид державного соціального медичного страхування, яке охоплює все чи переважну більшість населення країни). У розумінні обов'язку держави створити його й забезпечити обов'язковим медичним страхуванням кожного [8, с. 289-290].

Добровільне та обов'язкове медичне страхування є різними організаційноправовими явищами. Держава при запровадженні обов' язкового медичного страхування зобов' язана буде створити спеціальну публічно-правову інституцію. Приміром, Фонд обов'язкового медичного страхування чи делегувати функщії представлення держави іншій державній інституції. Так, наприклад, М. Г. Телішевська та О. Б. Олексюк зазначають, що «створення окремого Фонду медичного страхування призведе до збілышення витрат у зв' язку з його організацією та дублювання ряду функцій, які нині покладено на Фонд соціального страхування з тимчасової втрати непрацездатності. Окрім того, потреби в медичному обслуговуванні та наданні допомоги 3 тимчасової непрацездатності, вагітності та пологів для працюючих зазвичай взаємозв' язані» [9, с. 310-311].

Крім того, за справедливою думкою В. Ю. Стеценко, інститут добровільного медичного страхування передбачає добровільне рішення людини або роботодавця стосовно його співробітників про укладення договору медичного страхування з відповідною організацією та сплату страхових внесків. Даний вид медичного страхування забезпечує певний вибір лікувально-профілактичного закладу та лікаря, а також отримання якомога більш якісних, комфортних умов лікування. Добровільне медичне страхування є актуальним об'єктом юридичної науки, тому що за своєю правовою суттю є медичним страхуванням; певною мірою конкурує, доповнює, а іноді замінює обов'язкове медичне страхування; 3 позицій юридичного забезпечення держава неоднаково бере участь у добровільному страхуванні, порівняно 3 обов' язковим [10, с. 199-200].

Автору імпонує позиція А. Малагардіса та співавторів, котрі в межах виконання проекту Свропейського Союзу «Фінансування та управління у сфері охорони здоров'я в Україні» виокремлюють такі характерні ознаки проектів, орієнтованих на модель соціального страхування: солідарність фінансування (багатий платить за бідного); універсальна програма послуг для всіх застрахованих (справедливість); неконкурентна універсальна страхова система; відносно простий мехнізм управління. Своєю чергою, проекти, зорієнтовані на модель загальнообов' язкового цивільного страхування, характеризуються такими ознаками: регресивний характер фінансування (бідні платять відносно більше, ніж багаті); різні програми послуг залежно від суми страховки; створення конкурентних страхових ринків; складний механізм управління [11, с. 33]. 
Ситуація 3 покращенням моделі соціального страхування також може бути здійснена шляхом активного лобіювання громадськими організаціями питання запровадження обов'язкового медичного страхування, яке б забезпечувало доступність медичної допомоги [12, с. 83-84]. Відтак слід погодитися з В. Л. Федоренком, що зміст інституту лобіювання «полягає в легітимному впливі інститутів громадянського суспільства та бізнесових груп на органи державної влади з метою відстоювання власних законних інтересів під час прийняття нормативно-правових актів» [13, с. 206]. Можливість представити різного роду громадські інтереси під час запровадження обов'язкового медичного страхування є важливим соціокультурним фактором у формуванні системи стримувань і противаг в умовах побудови громадянського суспільства $[14$, с. 31-32].

Висновки. Отже, як видається, існує нагальна проблема України на сьогодні організація належної системи охорони здоров'я громадян, яка б забезпечувала доступність медичної допомоги. Одним із елементів цього, беззаперечно, є законодавче запровадження обов'язкового медичного страхування. Саме такого, яке буде організаційно-правовим та фінансовим дороговказом для розвитку організації надання медичної допомоги. Ідеться про те, що від якісно функціонуючої медицини багато в чому залежить реалізація права громадянина на отримання медичної допомоги i, за необхідності, його захист. Проблематика забезпечення доступності медичної допомоги є питанням загальнодержавного значення. Від його належного розв'язання багато в чому залежатиме ставлення пересічного громадянина до сфери охорони здоров'я та держави загалом. Проведення медичної реформи передовсім залежить від iї успіху в контексті доступності медичної допомоги, адже це - одна із головних характерстик медицини й охорони здоров'я загалом. Зволікати із запровадженням обов' язкового медичного страхування недоцільно. Наслідки нинішнього стану справ в охороні здоров'я буде непросто подолати.

\section{Використані джерела:}

1. Шатковський Я. М. Роль української медичної реформи в модернізації первинної ланки надання медичної допомоги. Пубиічне право. 2018. № 2. С. 132-137.

2. Нестерович В. Ф. Конституційно-правові види громадських обговорень. Вісник Луганського держаһного університету внутррішніх справ імені Е. О. Дідоренка. 2018. № 4. С. 38-45.

3. Стеценко С. Г. Конституційна норма про безоплатність медичної допомоги в Украйні: чиє необхідність внесення змін? Публічне право. 2015. №3. С. 40-48.

4. СіделковськийО. Л. Адміністративно-правова сутність публічної політики у контексті формування єдиного медичного простору Украӥни. Вісник Луганського держаһного університету внутріиніх справ імені Е. О. Дідоренка. 2019. № 4. С. 175-182.

5. Нестерович В. Ф. Роль громадськості у формуванні та реалізації державної антикорупщійної політики в Україні. Вісник Луганського державного університету внутріиніх справ імені Е. О. Дідоренка. 2016. №3. С. 5-13.

6. Конституція України. Відомості Верховної Ради України. 1996. № 30. Ст. 141.

7. Рішення Конституційного Суду Украӥни від 29 травня 2002 р. № 10-рп/2002 (справа про безоплатну медичну допомогу). Офіиійний Вісник України. 2002. № 23. Ст. 1132.

8. Стеценко С. Г. Конституційний Суд України як суб'єкт формування державної політики у сфері охорони здоров'я. Право України. 2013. № 5. С. 287-293.

9. Телішевська М. Г., Олексюк О. Б. Проблеми впровадження системи соціального медичного страхування в Україні. Медичне право Украӥни: проблеми становлення та розвитку: матеріали I Всеукр. наук.-практ. конф. (м. Льбів, 19-20 кВітня 2007 р.). Львів, 2007. С. 308-311. 
10. Стеценко В. Ю. Добровільне медичне страхування: правові засади регулювання. Публічне право. 2015. № 1. С. 197-202.

11. Реформування системи охорони здоров'я в Україні: досвід проекту СС «Фінансування та управління у сфері охорони здоров'я в Україні» / Малагардіс А., Рудий В., Ліннакко Е. та ін.; Проект СС «Фінансування та управління у сфері охорони здоров'я в Україні». [Посібник № 2. Вимоги до розробки стратегічного плану запровадження загальнообов'язкового державного соціального медичного страхування в Україні]. К.: СПДШмельков М. Ю., 2006. 72 c.

12. Нестерович В. Ф. Лобіювання як конституційно-правовий механізм захисту прав і свобод людини та громадянина. Вісник Академії правових наук України. 2010. № 3. С. 83-93.

13. Федоренко В. Запровадження інституту лобіювання в Україні: законодавчі та державно-управлінські аспекти. Вісник Національної академії державного управління при Президентові України. 2010. №. 1. С. 205-213.

14. Макушев П. В., Сибіряков С. О. Громадянська та правова культури як соціокультурний фактор у формуванні системи стримувань і противаг в умовах побудови громадянського суспільства. Право і суспільство. 2006. № 3. С. 31-37.

\section{References:}

1. Shatkovskyi, Ya. M. (2018) Rol ukrainskoi medychnoi reformy v modernizatsii pervynnoi lanky nadannia medychnoi dopomohy. Publichne pravo - Public Law, 2, 132-137. [in Ukrainian].

2. Nesterovych, V. F. (2018). Konstytutsiino-pravovi vydy hromadskykh obhovoren. Visnyk Luhanskoho derzhavnoho universytetu vnutrishnikh sprav imeni E. O. Didorenka - Bulletin of Lugansk State University of Internal Affairs named after E. O. Didorenko, 4, 38-45. [in Ukrainian].

3. Stetsenko, S. G. (2015) Konstytutsiina norma pro bezoplatnist medychnoi dopomohy v Ukraini: chy ye neobkhidnist vnesennia zmin? Publichne pravo - Public Law, 3, 40-48. [in Ukrainian].

4. Sidelkovskyi, O. L. (2019) Administratyvno-pravova sutnist publichnoi polityky u konteksti formuvannia yedynoho medychnoho prostoru Ukrainy. Visnyk Luhanskoho derzhavnoho universytetu vnutrishnikh sprav imeni E. O. Didorenka - Bulletin of Lugansk State University of Internal Affairs named after E. O. Didorenko, 4, 175-182. [in Ukrainian].

5. Nesterovych, V. F. (2016) Rol' hromads'kosti u formuvanni ta realizatsiyi derzhavnoyi antykoruptsiynoyi polityky v Ukrayini. Visnyk Luhans'koho derzhavnoho universytetu vnutrishnikh sprav imeni E. O. Didorenka-Bulletin of the Luhansk State University of Internal Affairs E. O. Didorenko, 3, 5-13. [in Ukrainian].

6. Konstytutsiia Ukrainy. Vidomosti Verkhoonoi Rady Ukrainy - Information of the Verkhoona Rada of Ukraine, 30, art. 141. [in Ukrainian].

7. Rishennia KonstytutsiinohoSudu Ukrainy vid 29 travnia 2002 r. № 10-rp/2002 (sprava pro bezoplatnu medychnu dopomohu). Ofitsiinyi visnyk Ukrainy. (2002) No 23. Art. 1132. [in Ukrainian].

8. Stetsenko, S. G. (2013) Konstytutsiinyi Sud Ukrainy yak sub'iekt formuvannia derzhavnoi polityky u sferi okhorony zdorov'ia. Pravo Ukrainy - Law of Ukraine, 5, 287-293. [in Ukrainian].

9. Telishevska, M. H., Oleksiuk, O. B. (2007) Problemy vprovadzhennia systemy sotsialnoho medychnoho strakhuvannia v Ukraini. Medychne pravo Ukrainy: problemy stanovlennia ta rozvytku: materialy I Vseukr. nauk.-prakt. konf. (m. Lviv, 19-20 kvitnia 2007 r.) - Medical Law of Ukraine: Problems of Formation and Development: Materials I All-Ukrainian. Research Practice Conf. (Lviv, April 19-20, 2007). Lviv, 308-311. [in Ukrainian].

10. Stetsenko, V. Yu. (2015) Dobrovilne medychne strakhuvannia: pravovi zasady rehuliuvannia. Publichne pravo - Public Law, 1, 197-202. [in Ukrainian].

11. Reformuvannia systemy okhorony zdorovia v Ukraini: dosvid proektu YeS «Finansuvannia ta upravlinnia u sferi okhorony zdorovia v Ukraini» (2006) Malahardis A., Rudyi V., Linnakko E. (Eds.) et al.; Proekt YeS «Finansuvannia ta upravlinnia u sferi okhorony zdorovia v 
Ukraini». [Posibnyk № 2. Vymohy do rozrobky stratehichnoho planu zaprovadzhennia zahalnooboviazkovoho derzhavnoho sotsialnoho medychnoho strakhuvannia v Ukraini]. Kyiv: SPD Shmelkov M.Yu. [in Ukrainian].

12. Nesterovych, V. F. (2010) Lobiyuvannya yak konstytutsiyno-pravovyy mekhanizm zakhystu prav i svobod lyudyny ta hromadyanyna. Visnyk Akademiyi pravooykh nauk Ukrayiny Bulletin of the Academy of Law Sciences of Ukraine, 3, 83-93. [in Ukrainian].

13. Fedorenko, V. (2010) Zaprovadzhennya instytutu lobiyuvannya v Ukrayini: zakonodavchi ta derzhavno-upravlins'ki aspekty. Visnyk Natsional'noyi akademiyi derzhavnoho upravlinnya pry Prezydentori Ukrayiny - Bulletin of the National Academy of Public Administration under the President of Ukraine, 1, 205-213. [in Ukrainian].

14. Makushev, P. V., Sybiryakov, S. O. (2006) Hromadyans'ka ta pravova kul'tury yak sotsiokul'turnyy faktor $\mathrm{u}$ formuvanni systemy strymuvan' i protyvah $\mathrm{v}$ umovakh pobudovy hromadyans'koho suspil'stva. Pravo i suspil'stvo - Law and society, 3, 31-37. [in Ukrainian].

Стаття надіӥшла до редколегї 12.02.2020

Шатковский Я. Н., кандидат юридических наук, старший научный сотрудник, докторант Запорожского национального университета (г. Запорожье, Украина)

\section{ВВЕДЕНИЕ ОБЯЗАТЕЛЬНОГО МЕДИЦИНСКОГО СТРАХОВАНИЯ КАК ПУБЛИЧНО-ПРАВОВОЙ ШАГ К ПОВЫШЕНИЮ ДОСТУПНОСТИ МЕДИЦИНСКОЙ ПОМОЩИ В УКРАИНЕ}

В статье рассматриваются вопросы внедрения обязательного медицинского страхования в качестве пути повьшения доступности медицинской помощи. Акцентируется внимание на существующих проблемах отечественного здравоохранения сквозь призму ее правового обеспечения. Критически воспринимается решение Конституционного Суда Украины, который указал на то, что право лица на медицинское страхование, предусмотренное в статье 49 Конституции Украины, это право на добровольное, а не обязательное медищинское страхование. Отмечается о различиях добровольного и обязательного медицинского страхования.

Ключевые слова: обязательное медицинскоестрахование; доступность медицинской помощи; права пациентов, административное право; медицинское право.

Shatkovsky Ya., Candidate of law, Senior researcher, Doctoral student at Zaporizhzhya National University (Zaporizhzha, Ukraine)

\section{IMPLEMENTATION OF COMPULSORY MEDICAL INSURANCE AS A PUBLIC LEGAL STEP TO INCREASE THE AVAILABILITY}

The article discusses the introduction of mandatory health insurance as a way to increase the availability of health care. Attention is paid to the existing problems of national healthcare through the prism of its legal support. 
An important factor in improving the availability of health care is the legislative introduction of mandatory health insurance. This step, which, while maintaining free medical care in state and municipal health care facilities, is able to provide a new organizational and legal and financial nature of the relationship between the various entities involved in the provision of medical care.

The decision of the Constitutional Court of Ukraine, which stated that the right of a person to health insurance provided for in Article 49 of the Constitution of Ukraine, is a right to voluntary, not compulsory health insurance, is critical. The differences between voluntary and compulsory health insurance are noted.

There is an urgent problem in Ukraine today - the organization of a proper public health system that would ensure the availability of medical care. One element of this is undoubtedly the legislative introduction of compulsory health insurance. Insurance, which will be the legal and financial guideline for the development of a medical care organization. It is a matter of the fact that the realization of a citizen's right to receive medical care and, if necessary, his or her protection depends on the quality of functioning medicine. The issue of ensuring the availability of medical care is a matter of national importance. Its decision will largely depend on the attitude of the average citizen to the health sector and the state as a whole. The implementation of medical reform depends first and foremost on its success in the context of the availability of care. This is one of the main characteristics of medicine and health care in general. It is not advisable to have to deal with the introduction of compulsory health insurance. The consequences of the current state of health are difficult to overcome.

Keywords: compulsory health insurance; availability of medical care; patients' rights, administrative law; medical law. 